\title{
THE POWER OF ARGUMENTS IN LEGAL RHETORIC
}

\author{
(Hukuki Retorikte Argumanların Gücü)
}

Filip NOVAKOVIĆ ${ }^{1}$

\author{
Derleme \\ Makale Geliș Tarihi: 10.06.2021 \\ Makale Kabul Tarihi: 02.12.2021
}

\section{ABSTRACT}

Argumentation or reasoning is the part of rhetorical activities in which the subjects of speech make statements that support their basic thesis, or do everything to convince listeners of the truth of their own, and the falsity of the claims of others. This is done in principle in order to convince certain subjects and thus direct their actions as the speaker arguing the claims wants. By this we mean that argumentation is a means, mechanism, or art of influencing human thought and behavior. This paper deals with this issue. The paper will systematically present the importance of argumentation for legal rhetoric. First of all, special attention will be paid to some basic concepts and clarification of the terms argument and argumentation. Then we will turn to the question of the theory of argumentation, where the author of the paper will present some of his views on these issues, and in connection with legal rhetoric. There will be a discussion on the importance of argumentation of the mind in oratory, and show what the power of arguments is in legal rhetoric through the example of judicial oratory. People use rhetoric on a daily basis and give reasons that go in their favor, that is, contrary to the claims of others. This is almost the rule in everyday speech. This issue is particularly important in the field of law. As the type and manner of presenting arguments (but also argumentation errors) can significantly affect the outcome of a certain legal situation, we therefore consider it of great importance to study argumentation in legal rhetoric. I believe that this work will contribute at least a little in this field.

Keywords: Arguments, Rhetoric, Public Speech, Law, Legal Defense, Logic, Errors In Argumentation.
DOI: 10.53507/akademikdusunce.950459

\section{ÖZ}

Tartışma veya akıl yürütme, konuşma öznelerinin temel tezlerini destekleyen açıklamalar yaptığ 1 veya dinleyicileri kendi hakikatlerine ve başkalarının iddialarının yanlışlığına ikna etmek için her şeyi yaptığı retorik faaliyetlerin bir parçasıdır. Bu, prensipte, belirli konuları ikna etmek ve böylece iddialarını savunan konuşmacının istediği gibi eylemlerini yönlendirmek için yapılır. Bununla, argümantasyonun insan düşüncesini ve davranışını etkilemenin bir aracı, mekanizması veya sanatı olduğunu kastediyoruz. Bu makale bu konuyu ele almaktadır. Makale sistematik olarak hukuki retorik için argümantasyonun önemini sunacaktır. Her şeyden önce, bazı temel kavramlara ve argüman ve argümantasyon terimlerinin açıklanmasına özel önem verilecektir. Ardından, makalenin yazarının bu konulardaki bazı görüşlerini ve hukuki retorik ile bağlantılı olarak sunacağ 1 argümantasyon teorisi sorununa döneceğiz. Hitabette aklın argümantasyonunun önemi üzerine bir tartışma yapılacak ve argümanların gücünün hukuki retorikte ne olduğu adli hitabet örneği üzerinden gösterilecektir. İnsanlar her gün retoriği kullanırlar ve kendi lehlerine, yani başkalarının iddialarına aykırı gerekçeler sunarlar. $\mathrm{Bu}$, günlük konuşmada neredeyse kuraldır. Bu konu özellikle hukuk alanında önemlidir. Argümanları sunmanın türü ve tarzı (ayrıca argümantasyon hataları) belirli bir yasal durumun sonucunu önemli ölçüde etkileyebileceğinden, bu nedenle argümantasyonu yasal retorikte incelemenin büyük önem taşıdığını düşünüyoruz. $\mathrm{Bu}$ çalışmanın bu alana en azından bir nebze de olsa katk1 sağlayacağına inanıyorum.

Anahtar Kelimeler: Argümanlar, Retorik, Topluluk Önünde Konuşma, Hukuk, Yasal Savunma, Mantık, Argümantasyondaki Hatalar.

\footnotetext{
${ }^{1}$ Faculty of Law, University of Banja Luka, Bosnia and Herzegovina, filip.novakovic@student.pf.unibl.org ORCID: 0000-0001-9979-5824
} 


\section{Introduction}

All people use speech on a daily basis. Regardless, not every speech can be considered the same. In this regard, depending on the situation, speech is evaluated by different criteria. This is the difference between ordinary, everyday speech and public speech. Public speaking is a presentation of the views of the speaker himself, addressed to the selected audience, with the aim of convincing the listener of the correctness or truthfulness of these views. Rhetoric or the art of persuasion (as Aristotle calls it) is one of the oldest disciplines whose roots can be found in ancient Greece. The beginning of rhetoric as a discipline also meant the beginning of the study of arguments as the primary means of persuasion which speakers should use continuously in their speeches. Thus Aristotle, in his famous work Rhetoric, gave perhaps the most famous definition of this discipline. According to him, rhetoric is the art of finding the convincing at any given moment (Aristotle, 2008: 37). In the same work, he emphasized the importance of argumentation in rhetoric in general. He gave a definition of argumentation, described ways of persuasion and speaking techniques, and emphasized the importance of objective and logical argumentation as something that should represent the core of rhetorical teachings (Ibidem, 38). Convincing someone is very difficult without valid arguments. Therefore, knowing the term argument and argumentation is extremely important, especially for someone who uses them every day. In addition to knowing the concept and elements of the argument, it is also necessary to know the errors in argumentation. It is necessary to know when and how to use an adequate combination of arguments in order to convince the audience or listeners of the truth or correctness of the statement he is speaking. Aristotle states that everyone, to a certain extent, tries to discuss and support an opinion, that is, to defend and accuse (Tadić, 1995: 130), that is, to speak in favor, i.e. against something. To advocate or refute one position.

\section{Basic Terms}

When studying this topic, it is necessary to distinguish several central concepts. First of all, we must know the meaning of the term argument (lat. Argumetum, proof, explanation, reason, justification) (Klaić, 2012: 73), then the term argumentation (proving, reasoning, way of presenting and arranging evidence) (Klaić, 2012: 73). The great Croatian professor of rhetoric Ivo Škarić in his work Argumentation pointed out that the use of evidence and proof, which belongs to scientific methods, seeks to reach the truth, while the goal of argumentation is to present something as truth, i.e. to convince others of the truth of a statement. some claim as truth (rather than checking or proving whether the satiety is true or not). According to Škarić, in public discourse the truth is the one to which nothing contradicts, and the rhetorical truth is 
the one that no one contradicts, the relationship is the one on which there is consensus (Škarić, 2011: 13). In the argumentative theory of understanding concepts, argument and argumentation vary depending on time and the prevailing philosophical understandings, and depending on the favoring of a logical, dialectical or rhetorical approach. Grgić believes that in the past argument, argumentation and argumentation theory were very often used as synonyms, but today the terms are clearly defined and differentiated (Grgić, 2016: 6). We agree with that view. We see the reason for this in the existence of precise and clear meanings of these terms both in rhetoric and in philosophy and logic. The first significant rhetorical definition of argumentation is found in Sloane's Encyclopedia of Rhetoric, which states that argumentation is "the study of reasoning used by people to justify their beliefs and values and to influence the opinions and actions of others" (Sloane, 2001: 33 ). This is considered to be the definition of argumentation in the sense of argumentative theory where the study of reasoning is viewed as theory, while reasoning itself is viewed as argumentation. On the other hand, the definition of argument in rhetoric can be found in the work Encyclopedia of Rhetoric and Composition by Therese Enos, which states that argument is first of all a process of polemics, disputes, conclusions and criticism, then dialectical and dialogical procedure of use in discussion and debate. and statement. Thus we see that this author followed Wenzelo's division of the notion of argument (Enos, 1996: 16-17). In addition to rhetorical explanations, there are other definitions of argument and argumentation offered by authors of different profiles (linguists, philosophers, logicians and others). Authors who base their understandings on the foundations of old logicians emphasize the relationship between the very elements of argumentation, i.e. the logic and rationality of reasoning (Grgić, 2016: 7). Weston thus points out that to argue something means to offer a series of reasons or evidence in order to support a conclusion, and for arguments he says that they are attempts to rationally support an opinion (Weston, 2000: xi). It is thought that Weston's definition actually presents argumentation as a rational explanation of a particular claim, which makes no sense. On the other hand, Johnson presents argumentation as a sociocultural activity of designing, presenting, interpreting, criticizing, and revising arguments (Johnson, 2000: 12). The Johson team emphasizes the sociocultural dimension of argumentation and says that it is an activity that develops in real communication between people (thus moving away from formal argumentation that is characteristic of theory and closer to informal).

In addition to understanding the concept of argumentation, it is very important to understand its purpose. Namely, the goal of argumentation is that it should be supported by a certain statement with certain evidence, i.e. that the one who presents the statement to certain 
facts convinces the audience or interlocutor of the truth or correctness of that statement. Walton thus states that to argue something know how to give reasons that support or refute a particular claim that is disputable or questionable, and states that the purpose of argumentation is to offer a reason or more that support a particular claim in which there are doubts and will remove the same doubts. He also adds three essential goals of critical argumentation that are reflected in the identification, analysis, and evaluation of arguments (Walton, 2005: 1)

In addition to logicians, it is very important to note the understandings of individual dialecticians. In this sense, we cite the definition of Van Emeren and Grootendorst who state that argumentation is a verbal, social, and rational activity aimed at convincing a reasonable critic of the acceptability of a claim by making a set of propositions that prove or disprove the stated position (Van Emeren and Grootendors, 2004: 1). The definition that dialects offer is more or less similar to that offered by logicians. We see the difference in the existence of a reasonable critic who should be convinced by arguments that the statement is correct, that is, the choice of the audience to which a certain type of argument will be presented is significant. Thus, we can conclude that there are arguments that can only be presented to a reasonable critic who is part of a particular audience. Thus, some emphasize the difference between dialectics and rhetoric. Dialectics chooses audiences, rhetoric does not. In his Handbook of Argumentation Theory, Van Emeren presented a newer definition of argumentation: „Argumentation is a communicative and interactive set of actions aimed at resolving differences of opinion between interlocutors in such a way that the person arguing presents a set of his own proposals. the debate should be made acceptable to a reasonable judge who judges prudently" (Van Emeren et al., 2014: 7). This definition emphasizes a dialogical character of argumentation, presents it as an interactional set of different actions, and in accordance with the dialectical tradition, strives for the goal of overcoming opposing views, that is, it wants to resolve differences in opinion. Furthermore, it is pointed out that they should be addressed to someone who is reasonable and judges prudently, that is, the argumentation is intended exclusively for such an audience. Rhetoricians alike emphasize rationality as a major feature of argumentation. Thus, Škarić states that argumentation is the adaptation and shaping of a text, which is obtained rationally. However, perceptions are misunderstood when it comes to this characteristic of arguments (Škarić, 2011: 13). Namely, unlike rhetoric, dialectics (as well as logic) represents rationality as the main quality of argumentation towards which it aspires, and which is objectively evaluated according to established criteria, while rhetoric aims to appeal to reason with the audience through argumentation (as opposed to appealing to 
emotions). then when she wants the audience to accept the claim in common sense, that is, to accept it because it seems logical (and not because it touched them emotionally) (Grgić, 2016: 8-9). Some authors, interpreting Škarić, point out that the goal is not prudence of argumentation, but that the goal is persuasion by appealing to common sense. So, the goal is not to make the argumentation reasonable, but to make the audience think it is reasonable, and therefore to be convincing to them. Grgic believes that the rhetoric of reasoning is subjective and changeable (Grgić, 2016: 9), which is quite logical, because each speaker will always choose those arguments that he believes will convince the audience of the correctness of a particular statement he advocates, because it will sound and look reasonable. It is the speaker who decides what combination of arguments he will use, that is, what the quality and quantity will be, depending on the audience that will listen to him. Zarefsky argues that the core of argumentation is actually that argumentation implies the justification of statements. $\mathrm{He}$ investigates the argument by asking on the basis of which a conclusion is accepted, what makes those bases valid and how do we know that these are the bases, while the bases or foundations here represent the premises (arguments) from which a conclusion is drawn, ie some claim. It relies on a narrower definition of argumentation offered by logic, but also emphasizes its rhetorical dimension, stating that it is important, in addition to the fact that the foundations are valid, to examine why a conclusion is accepted or why it is convincing (Zarefsky, 2014: xv).

\section{Theory Of Argumentation}

We can say that the development of the theory of argumentation was directly conditioned by the development of logic, rhetoric, dialectics and philosophy in general, and their views and different approaches to argumentation. These different views were grouped by the authors into three groups depending on which discipline this approach is inherent in: (1) argumentation as a process (approach inherent in rhetoric), (2) argumentation as a process (approach inherent in dialectics) and (3) argumentation as a product (approach inherent in logic) (Grgić, 2016: 4). Rhetoric is a commitment to the study of the entire communication process during which the audience is presented with a certain topic, a certain attitude. It is necessary to substantiate this fact with facts that would support its truth. In this regard, argumentation is the most powerful weapon of rhetoric, with the help of which the speaker should convince the audience of the correctness of his position. However, one should be careful with the arguments in the rhetoric and one should not lightly engage in presenting evidence on a certain claim without prior preparation. An argument in rhetoric can be a double-edged sword, because the use of inadequate or wrong arguments can lead to a counter-effect. No matter how correct or true the 
position advocated by the speaker, if he/she chooses the wrong argument the audience may conclude otherwise. Rhetoric has a significant relationship between the audience and the arguments presented, and wants to find the best possible way to convince listeners of the correctness of some of the allegations by using the most adequate arguments. Dialects, on the other hand, is very interested in establishing the rules of a particular procedure that should lead to a productive critical discussion between two proponents of opposing views. Critical discussion will be productive when it leads to overcoming disagreements and reaching consensus on an issue. The goal of dialectics in this regard is to create a framework in which to shape and direct the argumentative interaction of the participants in the discussion in order to reach a true or the best conclusion together. Logic is the art of correct thinking, reasoning, debate, and is a fundamental philosophical discipline that deals with correct forms of thinking, understanding judgments, and reasoning. This philosophical discipline is interested in how to write that the conclusion logically follows from the premise, and which premises to choose and how to deal with them in order to prove or support a conclusion in the best possible way. Rhetoric gives importance to convincing the pulbica of the correctness of an attitude, dialectics is important to constructively resolve differences of opinion, while logic is aimed at the logical validity of the conclusion. All three of these disciplines strongly consider argumentation to be an important tool in pursuing their goals. All three disciplines study argumentation and give it equal importance.

The authors believe (e.g. Zarefsky, Wenzel, Freeman) that the systematization of knowledge in the theory of rhetoric is quite problematic. True, rhetoric provides excellent instructions, methods, and ways to use arguments. However, the notion of successful persuasion differs from the situational context, because in rhetoric there are no two identical situations (Grgić, 2016: 5). Unlike rhetoric, dialectics and logic have devised rules and methods of using arguments on universal criteria, and they can be used effectively in every situation. Although the systematization of the collected knowledge about argumentation and the systematization of rules and methods of its application in dialectics and logic have been done more clearly, the rhetoric gives a special charm of situational uncertainty which undoubtedly presents a challenge for every speaker. We believe that this is where the beauty of rhetoric lies, because the impossibility of using the same combination of rules and methods of using arguments leaves a huge room for maneuver for the speaker to show all his/her skill, all his/her rhetorical gift and his imagination. It reflects top speakers (such as Theodor Rosevelt, Abraham Lincoln, Winston Churchill and others). The main virtue of top speakers is their adaptability to 
different situations and finding the right arguments at the right time. We believe that each position can be represented by a different combination of arguments depending on the situation in which the speaker finds himself. Thus, for example, the same combination of arguments will not be used when presenting a certain (identical) position in front of members of the academic community, members of parliament or when approaching a certain problem to the common people. The top speaker will, in each situation, depending on the topic of his/her speech and the audience that listens (whether they are politicians, academics, soldiers, ordinary citizens, etc.), handle different combinations of arguments and adjust his speech to convince listeners of the correctness or the truthfulness of the position he advocates. Thus, the combination of arguments that one auditorium can convince of the correctness or truthfulness of an attitude, can provoke the opposite reaction in the audience of another milieu. Radonjić believes that finding the best (most suitable) method of persuasion in one speech is an extremely complex and subtle job (Radonjić, 1999: 99).

Each scientific discipline has made a certain contribution to the theory of argumentation. Each presented the problem from their own point of view and offered a solution that she considered most acceptable. Of course, it is very difficult to determine which of these attitudes is the most correct. A large number of theorists (Tindale, Johnson, Blair, Groarke, Eemeren, Grootendorst and others) believed that the symbiosis of previously set concepts should be applied in the most ideal situation. In that symbiosis, either a rhetorical or a logical or dialectical element would prevail. Opinions are that in some situations perhaps all three should be equally represented. We are of the opinion that the speaker should be the one who decides what to use and which way to use in which speech. That is why comprehensive research before giving a speech and its preparation is of great importance. We believe that the rhetorical element should be predominant in any case. We do not consider this to be negligible or less important in the dialectical and logical approach. We emphasize that the speaker must pay special attention to them during his research, as well as to the research of the audience that will listen to the speech. That is all before necessary preparation. However, the situations in which the speaker will find himself are quite different and depend on many factors. No matter how much the speaker prepares, that preparation does not give him a guarantee that he will convince the audience of the correctness or truthfulness of his position. At the moment of appearing in front of the audience, the speaker gets acquainted with the actual situation on the ground depending on which combination of his/her arguments he/she adjusts in order to achieve the goal, ie to convince the audience of the correctness or truth of the position he represents. 
One of the greats of English philosophy, John Stuart Mill, in his work A System of Logic pointed out that we must observe not only good but also bad forms of reasoning, in order for the philosophy of reasoning to be complete (Tindale, 2007: 1). Guided by his thought, a large number of philosophers and authors dealing with argumentation, logic and rhetoric give considerable importance to the study of erroneous argumentation (e.g. Aristotle in On Sophistic Rebuttals, Charles Hamblin in his book Fallancies, John Locke, John Woods and others). The first definition of erroneous argumentation can be seen in Aristotle, who states that some forms of inference are good, and some only look good, but are actually wrong (Kišiček, 2010: 131). Hamblin states that the wrong argument only looks like a correct one, but he is not (Hamblin, 1970: 12). Wahtley calls errors any unreasonable and erroneous way of arguing (Schmidt, 1986: 2), while Tindale defines error as a specific way of erroneous reasoning that seriously undermines the power of a rational argument (Tindale, 2007: 1). Tindale is perhaps most important for post-Hamblin theorizing argumentation. We see the reason for this in his explanation of why errors in argumentation occur at all. Namely, we use arguments in rhetorical speech in different situations and in different forms to convince the audience of the correctness of our claims, to indicate the initiation of an action or to overcome disagreements and reach consensus on an issue. Precisely because different arguments are used depending on the situation, they have a different intensity of strength. Just as one argument can be strong and unequivocal in one situation, it can be completely wrong in another. Tindale's thinking supports our thesis.

The first systematization of erroneous arguments was made by Aristotle. He divides errors into two categories: (a) paralogisms and (b) sophisms. Paralogisms are unconscious, involuntary mistakes we make without the intention of deceiving or misleading someone, while sophisms are a group of mistakes we make with a special intention to confuse or manipulate an opponent or audience. In addition, Aristotle compiled a list of thirteen errors and divided them into two groups (fallaciae dictionis - errors dependent on language, which arise from the misuse of words or grammatical structures, etc. and fallaciae extra dictionem - errors independent of language, which arise from erroneous inferences), and later Roman rhetoricians gave them Latin names (Kišiček, 2010: 131-132). The English philosopher Richard Wathley divides errors into logical and material. The former occur when the error is exclusively in the process of reasoning (for example, that the conclusion does not follow from the premise), while in other situations it is a little more specific. Namely, although the conclusion follows from the premise, the error occurs due to some other reason (for example, one or more premises may be incorrect, 
irrelevant or unsubstantiated). Wathley divides material error into ignorantio elecnhi and petitio principii (Schmidt, 1986: 3). In the first case, it is an irrelevant conclusion or a missed topic, while in the second it is a logical error in proving, ie a claim is proved by something that has not been previously proven, and is taken as safe evidence. We are also interested in W. Ward Fearnside's understanding that he connects the process of argumentation with the process of weaving. Namely, he believes that mistakes can be divided into three groups: psychological (argumentum ad populum, ad hominem, ad ignoratiam, ad baculum and others, which can have different effects on the audience or interlocutors, either offensive, or flattering, or intimidating), material (error resulting from generalization from incomplete information, e.g. petitio principii, slippery slope fallacy / mistake, composition and division, post hoc ergo propter hoc) and logical (errors of analogy, accident and consequence). He believes that just as mistakes can occur in fabric production, so they can occur in thinking. We can have bad material, workers can be unprofessional and equipment can be broken (Fearnside, 1980: 13). When this is transferred to the field of argumentation of claims in rhetoric, we can easily see why Fearnside made such a comparison. Another notable author sources an interesting classification of errors that differs from his predecessors. Namely, Munson does not classify errors according to their origin but according to the role they play. Thus, instead of the usual classification of errors according to whether they are due to misuse of language, prejudice, errors in reasoning, proof, etc., it divides according to whether it is aimed at (i) arguing the claim we make, (ii) refuting someone else's claim or (iii) refuting the counter-arguments. According to these criteria, Munson divides errors into the following three groups: 1. errors, 2. sophistic refutations, and 3. sophistic defenses (Schmidt, 1986: 5; Kišiček, 2010: 133).

The study of logical errors experiences its expansion in philosophy and with great reliance on Aristotle. In this regard, modern philosophers most often divide errors into formal and informal. The first is a form of inference that is not valid due to an error within the formal logical structure of the argument, while in the second case we will have an error if the conclusion is wrong due to the invalidity of one of the premises, regardless of the validity of the argument structure. Gupta, for example, divides errors into formal, including syllogistic, qualifying, and propositional, informal, including distribution errors, equivocation, petitio principii, erroneous generalization, and others, and conditional errors, including slippery slope, broken window fallacy, and others.

Today's argument theorists, among whom the most famous are Tindale, Weston, Thogard, Freley, and Steinberg and Walton, pay special attention to the errors that occur in 
everyday communication and public speaking. Tindale distinguishes between errors of diversion (irrelevance), errors dependent on language, errors on structure, errors on cause-andeffect relationships, errors in analogy, argumentum ad ignorantiam, ad hominem, ad verecundiam and others. In his works, he cites very vivid examples from everyday life (media, communication, public speeches) for each mistake (Tindale, 2007: 117). Tindale was versatile in the study of argumentation errors, while Walton paid special attention to errors of irrelevance (although in his work he also mentions argumentum ad populum and ad hominem) (Walton, 2006: 84-128). He states that there is a thin line between errors in argumentation and that it can almost be put under the error of irrelevance (Kišiček, 2010: 135). Weston points out that certain errors are so common that they got their names, however he refuses to make a more complex classification and states that there are two major errors: I. generalization error from incomplete information and II. the error of neglecting alternatives (Weston, 1992: 52). Authors Freely and Steinberg divide errors into four major groups: a) errors in obviousness (unverified data, erroneous examples), b) erroneous in reasoning, or logical connections (erroneous inference, erroneous analogy, erroneous causal relationships), c) language errors (ambiguous or ambiguous expressions, oversaturated language) and d) pseudo-arguments (errors of irrelevance, circular argumentation, attack on the opponent, populism, complex issues) (Freely and Steinberg, 2005: 173). Finally, Thogard introduces a new division of argumentative errors, pointing out that no one before him has made a qualification of errors concerning practical reasoning, concerning what should be done, not thought. Thus, he divides the errors of practical reasoning into three groups: the first group consists of neglecting relevant alternative procedures, the second neglecting relevant goals, while the third group makes errors in choosing the best way to achieve the goal (Thogard, 1983: 26). Among our most important rhetoricians is the prominent Croatian theorist of argumentation Ivo Škarić, who in his work Script for Mentors of the Speaking School gave an overview and classification of the most significant and most common mistakes. He uses Weston's classification, and Schopenhauer's heuristic tricks, as Kišičić states, which he supplements with his own examples (Škarić, 2004: 76-87; Kišiček, 2010: 136-137). He emphasizes the necessity of recognizing false arguments and knowledge of eristic dialectics with the aim of easier coping in cases when we are confronted with unsubstantiated subterfuge in communication (Škarić, 2011: 85-88, 89-97).

Why is so much attention paid to the study of errors in argumentation by some of the most significant names in philosophy, logic, and rhetoric? In order to better understand argumentation alone, it is crucial to know the errors in argumentation. It is important to know 
them or the reason of their easier avoidance and correction as well. Reading uthors who deal with this topic, from Aristotle's time to the present day, rhetoricians, public speakers, politicians and other professionals who deal with public speech, regardless of their talent, must master the techniques of combining arguments depending on the situation in which they find themselves. For this reason, it is important to know and distinguish argumentation errors. This is also very important to those who use legal rhetoric. Knowledge of argumentative errors can greatly contribute to the classification and better combination of arguments in public speaking (here we can take for example lawyers who if they fail to substantiate their allegations with the right combination of arguments can lose the case in court, regardless of the truth or correctness of evidence on his side).

\section{The Importance Of Argumentation in (Legal) Rhetoric}

Mayer sees rhetoric as negotiating the difference of individuals on a given topic, the backbone is an issue that creates contradictions (Mayer, 2008: 196). The previous position is just one of many that have emerged in the twentieth century, and which introduce some novelties into the rhetoric. Novelties that lead to the creation of new theories, but also directions. If we assume that each question that is asked has alternatives shaped into two opposing positions, then the goal to be achieved is to eliminate one of them. That elimination should lead to the final truth on some issue. We believe that this is precisely the goal of argumentation. Some authors believe that the goal of rhetoric is an agreement between opposing parties who represent different positions for the common good. They also state that this created a vision of rhetoric as an art of persuasion, but also of seducing the audience with its specific style (Mirković, 2014: 10). It is believed that the rhetoric of the question it represents most often leaves it open by seducing the audience with its specific style, while argumentation, unlike rhetoric, brings the problem and the question to light. This is considered to be an approach that opposes rhetoric and argumentation. As the rhetoric is focused on convincing the audience, it puts the emphasis on the audience itself more than on the validity of the argument. He presents the arguments with his specific styles and leaves the audience to decide whether the arguments are valid or not. Thus, rhetoric is focused on convincing the audience, and persuasion is based on rhetorical argumentation (Mirković, 2014: 10). The authors believe that rhetorical argumentation has a foothold in the speaker's effort to increase the audience's affection for one of his claims (Tindale, 1999: 69). Billing believes that rhetoric is a traditional discipline that uses argumentation that provides insight into understanding and reasoning (Tindale, 1999: 1). All of the above leads us to the conclusion that there is a very strong 
connection between rhetoric and argumentation. This connection is not only present in academic circles or in politics. No, it is present in many more social spheres. It is present in the media, in everyday communication, in marketing and of course in law, primarily thinking here of the connection between argumentation and rhetoric that we notice when reviving rights in the courtroom. Adhering to Aristotle's triad (process, procedure and product) we see that dialectics as a discipline is more focused on the rules of procedure of argumentative discussion, while rhetoric is directed towards the study of the comic process conscious of argumentation. Mirković believes that the audience is not passive, but has the role of an evaluator (Mirković, 2014: 11). Arguments aimed exclusively at particular audiences, Perelman and OlbrechtsTyteca say, explaining the importance of audiences in rhetorical argumentation, result in the speaker adapting to his listeners using arguments that may be unacceptable or even contrary to another audience (Perelman and Olbrechts-Tyteca, 1969: 30). Why does the importance of the audience stand out so much? Why do so many authors do this, and not just Perelman or Obrechts-tyteca? As we have already stated, the audience has the role of evaluator, the final judge. It is the audience that will evaluate the correctness of the speaker's position based on the arguments offered. Thus, for example, a single judge or a trial chamber assesses the veracity of the allegations of the prosecution or the defense based on the strength of the arguments presented by both. These are not only the case in court proceedings, but also in everyday communication or during political and other speeches. The audience makes the final judgement.

The importance of the audience is also shown by the fact that a distinction must be made between a particular and a universal audience. This division was presented by Perelman and Olbrechts-Tyteca in their work New Rhetoric (Perelman and Olbrechts-Tyteca, 1969: 32). Why is it important to distinguish them? Namely, when a speaker addresses a particular audience, simply put, he addresses an audience that is often prone to prejudice or bias, and has become a speaker with considerable difficulty. Because of these prejudices, the particular audience can very often challenge even the most correct views supported by the most valid arguments. On the other hand, when a speaker addresses a universal audience he is addressing listeners who in most cases go beyond prejudices or some particular attitudes. When addressing the universal audience, the speaker is obliged to convince him of the absolute and timeless validity of the reasons, ie arguments. But even that audience is much more ready to accept them than the particular audience.

According to Škarić, argumentation is a rhetorical process of text formation that is acquired common sense (Škarić, 2011: 13). Thus, during the sermon, the speaker presents the 
reasons for which he represents a certain position, that is, he argues the pronounced court in order to be understood and accepted in a reasonable way. Fahnestock and Secor argue that the argument consists of four basic elements. The first is a statement related to probability, the second is the audience trying to convince the truth or correctness of the statement, the third is reflected in the requirement to create an argument at a certain time and situation, while the fourth element refers to the foundations, fromal called premises, which support the claim (Fahnestock and Secor, 2004: 23).

Some authors believe that there are four main areas of argumentation, including four types of assertion. The first is a factual assertion. It tells us about the nature of things, that is, it tells us what something is, and doubt is created about such a thing. The second type are value claims that refer to the question of what something is, and thus people, actions and things are valued. We talk about cause-and-effect claims when we want to talk about why something is, that is, when we want to explain causality. The last type of claims are political claims (which are most often in public discourse), and which are reflected in making suggestions or realizing plans for the future. We use them when we ask what to do (Mirković, 2014: 12).

The last thing we should say here are the pillars of argumentation. Škarić states that in support of the argument of logical connection and obviousness (Škarić, 2011: 21). According to Mirković, the initial dissent in the presentation of the claim is annulled in such a way that the speaker presents to the audience what he considers to be obvious to the audience, that is, known, and therefore acceptable. In this way, the well-known is more strongly connected with the claim in order to make it clearer and more acceptable (Mirković, 2014: 12). This is supported by Škarić's thesis that "obviousness is an article in an argument that is in itself acceptable to the audience" (Škarić, 2011: 25). According to him, the obviousness can be: a) fact, b) data, c) authority, d) quotation, e) example (case, illustration), f) proof, d) topos and h) definition (škarić, 2011: 25). Perelman calls these arguments arguments based on the structure of reality, ie an argument based on examples and illustrations, which by their facts support the service of argumentation because they are really an argument in themselves (Perelman, 1982: 11). It is felt that when evaluating arguments, there are strong and weak arguments. Strong are those arguments that are with acceptable premises and the conclusion that follows from them (Groark and Tindale, 2008: 140). The audience needs to be convinced by a strong argument, but it is considered that a rare argument is so strong that it cannot be answered. A weak argument is one that lacks acceptable premises or a conclusion that follows from them or both (Groark and Tindale, 2008: 140). A weak argument as a rule omits the audience's belief. That 
is why the speaker must handle the arguments well and prepare well. The strength of arguments, states Škarić, in gaining does not lie in the strength of the truth they present, but in the belief of the listener that what was stated could be true (Škarić, 2011: 13). This is why argumentation is extremely important.

\section{Judicial Rhetoric (Oratory) and Argumentation}

The Roman law left us an important legal saying - Ius est ars boni et aequi (law is the art of good and equal, although some authors translate the term ars as a skill). Adhering to it, we constructed Iustitia, the goddess of justice who holds a scale in her hand with a blindfold on it, in order to be impartial and balance arguments, and she cuts with a sword which is a symbol of judgement Avramović, 2008: 279). The Romans also put together a legal maxim for us, in fact an ideal that we should strive for, and that is justice. According to the Romans, justice is reflected in an honest life, not insulting anyone and acknowledging to everyone what belongs to him (Iuris praecepta sunt haec honeste vivere, alterum non laedere et suum cuique triburere). Legal rhetoric, which is primarily reflected in court nonsense, should be in the function of that noble goal which is reflected in the realization of justice and fairness (Avramović, 2008: 279; Nušić, 1934: 55; Radonjić, 2006: 23; Petrović, 2007: 319). As we have emphasized, legal rhetoric is best recognized in court rhetoric, to which special attention has been paid throughout history. The old authors (Aristotle, Cicero, Quintilian) especially emphasized this type of rhetoric, and even emphasized that it may have priority over other forms of rhetoric. Judicial speech, unlike political speech, Avramović believes, is much less susceptible to manipulation, primarily due to a more qualified audience and, of course, the quality of arguments, and even the very act of communicating them (Avramović, 2008: 381). Nonetheless, court oratory, like any other, is largely subordinate to the audience. What kind of audience will depend on many factors, but above all, the type of court stands out. Antiquity abounds in jurors, secular courts that needed to be amazed by both the arguments presented and the way they were presented. The jury can be much more influenced than with the soul of an individual or the trial chamber by using emotions. It is believed that the power of speech can often be more influential on the decision itself than the power of the arguments presented in that speech. For these reasons, judicial rhetoric, and thus legal rhetoric, developed most in ancient Greece and ancient Rome. The continuation of this development was significantly slowed down by the dark Middle Ages, which is reflected in quite unfair and incorrect trials, the existence of judicial arbitrariness and the strong influence of the Church. The development of legal rhetoric is reviving in the countries of the Anglo-Saxon legal system, and then in 
Europe. The development of judicial rhetoric was more susceptible in England, the United States, and countries under their legal influence. As a reason for that, we cite accusatory court proceedings and trials in which the jury has a significant role (Simović, 2016: 83-84).

It was these juries that posed the greatest challenges for lawyers, whose speeches sought to give greater strength to the arguments (evidence) presented during the trial. They tended with bombastic speeches with great deal and emotion to give more weight to their evidence and to persuade the jury to their side. As juries are primarily made up of lay people (it is rare to find, although not excluded, a legal expert), they can be more influenced by emotions and extrajudicial vocabulary, using less complex legal terms understood only by professional lawyers. With their speeches, they tend to bring the legal matter around the debate closer to the common people and have the freedom to present their case to them as they wish. These freedoms are held by very few of their counterparts engaged in practice on European soil. Namely, in Europe, the exclusively inquisitorial principle has been represented in court (criminal) proceedings, where the judge has a key role in the trial and sentencing, he seeks to present evidence and seeks to reveal the material truth (Simović, 2016: 85). Today, a mixed principle prevails, with European continental jurists giving much more importance to their speeches and ecoming one really powerful weapon in court battles.

Some develop the development of judicial rhetoric, and thus legal rhetoric, by the existence of a jury. Many advocate its introduction, pointing out that it expresses a general sense of justice and morality of the social community, and provides what is called the most vital expression of direct democracy (Freedman and Smith, 2004: 27). On the other hand, there are those who are in favor of its abolition. Le Bon believes that the rules of the crowd apply to the jury (submissiveness, poor reasoning, the influence of customs, prejudices, the predominance of unconscious feelings), and this can have a bad effect on law and justice (Le Bon, 1920: 105). However, without the jury, we would not have the development of judicial non-judgement and thus emphasize the great importance of the freedom provided to lawyers (primarily lawyers) in the accusatory procedure. Although the jury is made up of legal laymen, we point out that in accordance with legal ethics, lawyers primarily adhere to legal arguments and facts in their speeches, but we also note that they have the freedom to decorate and refine their speeches in accordance with general rules, methods and principles of legal rhetoric. rhetoric in general.

We will briefly review the content and strategy of the presentation of the court speech, and especially my argumentation in legal rhetoric. The main speech, as well as the court 
submission (when there is no possibility of speech, legal writing comes to the fore here, the language must be as simple and clear as possible in the submission), Avramović believes, should follow the logical structure to which the factual description of the disputed events, ie factography (Avramović, 2008: 401 and 406). This should be followed by a legal analysis indicating the relevant regulations that are applicable to the situation presented. Finally, a key argument leading to the desired conclusion should be presented (Avramović, 2008: 401-402). Gardner believes that there are three key parts of court speech - The Facts, The Law, The Argument (Gardner, 1993: 97).

One of the most delicate things, which reflects the professional skills and intelligence of good lawyers, good rights, is to choose the right, most important and most effective facts and arguments from the multitude of information he receives (Avramović, 2008: 402). In the previous sentence, we can see the explanation and the sentence ius est ars..., because law is, in addition to crafts and science, really also art. Therefore, it is necessary to make an objective assessment of the arguments that correspond and those that do not correspond (a distinction is made between good and wrong arguments). It is necessary to perform a legal analysis by rational reasoning and then create the right combination of the most adequate arguments that will be used in the speech. When the most adequate arguments are located, the most effective way of presenting them is devised, a rational allocation is made.

The above represents the strategy that will be used. During the preparation of the sermon, the lawyer puts himself in the boots of the general who is preparing for the battle. The preparation of the speech takes into account the selection of the most useful arguments and their combination in order to impose themselves on the audience and to achieve the best result. They usually do it by gradation, sorting the arguments so that they are understandable, that they derive from each other, they do that by starting the speech with weaker arguments, and as they move away, the argument becomes more and more powerful. When arguing, in their speeches, lawyers often refer to courts decisions, legal science (jurisprudence) and legal regulations. All this often makes the judge's job easier (provided that the combination of arguments used is adequate). In order to give the best, concise, clear and well-argued answer, it is necessary, during the court hearing, to pay special attention to listening to the other party and making notes that would serve as preparation for counter-fire, ie refuting the opponent's arguments with counter-arguments. Therefore, when listening, it is important to locate the other party's main arguments in order to properly agree on them. Avramovic states that this is possible in three ways. The first (and most common) is refutation with counter-arguments. The second option is 
reflected in the possibility to accept the other party's argument, but to apply the topic (so-called "yes, but..." approach, which adopts the opponent's claim, but points out that it is irrelevant and that there is another important argument). The third possibility is to ignore certain arguments of the other side, especially those that are, at first glance, obviously insignificant, and it is important to note ex plicite that this is done because of their importance (Avramović, 2008: 404-405). Great teachers of rhetoric believe that one should not waste time with too much detail. Too detailed speeches can tire the audience, leading to a refusal to accept the truth or correctness of a statement or claim. In addition, it is very important that the language of speech be as simple and clear as possible. It is significant to note one piece of advice left in this regard by the great Cicero. Namely, in his work De oratore $(2,72,294)$ he states the following: „I sometimes do not give any answer to an inconvenience or a difficult argument, which someone might rightly ridicule to a greater extent they force it into a fix. And retreat so as not to give the impression that I have rejected the shield, and even less that I have covered my back with it in the eyelid. Rather, in my speech, I give the impression of ornateness and escape under the guise of a fight: I am fortifying myself in my fortress so that it seems that I did not retreat to flee from the enemy, but to take up position“.

In addition to the content of the speech (which is very important), attention should also be paid to the way thoughts will be expressed. Reading the written text, stuttering, repeating the expression in the past can only negatively affect the final outcome. When speaking, the speaker must look fearless, he must look convincing, he must be emotional, passionate... He must act as if he lives what he says, but again he must behave in moderation. A cold, neutral, overly analytical and sterile speaker cannot reach the audience, just as an overly bombastic and emotional performance can be repulsive and cause a counter effect. Attention must be paid to caesura, language, tempo, diction, loudness, rhetorical questions, phrases... Everything must be well composed, just if a good symphony or waltz.

\section{Conclusion}

Rhetoric as an art of persuasion has a long history. It has been used as an adequate means of convincing audiences since ancient times (ancient Greeks, Romans). In order for someone to be a good speaker, and thus to convince the listeners of the truth or correctness of his claims, he must use certain arguments. Arguments are one of the most important means of persuasion in public speaking. They are a tool for achieving the ultimate goal, and that is to convince the audience that the position that the speaker represents is the only correct one, the only true one. Even the old teachers of rhetoric (Aristotle, Cicero, Quintilian) emphasized the great 
importance of argumentation when giving a speech. Much attention has been paid to the study of argumentation by a large number of modern authors. Argumentation is not only important in public speech, rhetoric, but it is not very important in logic, dialectics and philosophy in general. Using the right arguments, or rather the right combination of arguments at the right time and in front of the right audience, is the key to the success of anyone who deals with public speaking (whether he is a politician, lawyer, actor, journalist or something else). The power of arguments in legal rhetoric is great. And their proper use can only mean a ticket to success. People are used every day and give reasons for and against every day, thus opposing the views of the other party, ie the other speaker. So they try to prove that something is more correct than another, and something more incorrect. The impact of this phenomenon on everyday life is enormous. This impact is particularly evident in individual legal situations. That is why it is very important for a law student and young lawyers to dedicate themselves to the study of this noble skill. In addition, attention should be paid to the study of argumentation in general, and not only what is often presented as sufficient in rhetoric textbooks. They need to know which arguments are right and which are wrong. Like when an argument is right and when it is wrong. They need to learn which arguments are strong and which are weak and when they are strong and when they are weak. All arguments have a certain weight. A certain power. And it is very important to know their use well because even the best argument made in front of the wrong audience or at the wrong time means that you will not convince the listeners of the correctness or truthfulness of your claims. Must know how to prepare the right combination of arguments and how to properly arrange them in your speech in order to achieve the best effect, and thus success.

\section{Bibliography}

Aristotel.(2008). Retorika, UNIREKS, Podgorica.

Avramović, S. (2008). Rhetorike Techne, Veštinabesedništvaijavninastup, PravnifakultetUniverzoteta u Beogradui JP „Službeniglasnik“.

Enos, T. (1996). Encyclopedia of Rhetoric and Composition: Communication from Ancient Times to the Information Age, Routledge, New York.

Fahnestock, J., Secor, M. (2004). A rhetoric of Argument, McGraw Hill, Boston.

Freedman, M. H., Smith, A. (2004). Understanding Lawyers Etichs, Lexis Nexis, Newark.

Freely, A., Steinberg, D. (2005). Argumentation and Debate, Thomson\&Wadsworth, Belmont.

Gardner, J. A. (1993). Legal Argument, The Structure and Language of Efective Advocacy, Lexis Nexis, Charlottesville.

Grgić, S. (2016). Vizuelnaargumentacija u oglašavanju, FilozofskifakultetSveučilišta u Zagrebu, Zagreb.(napomena: diplomski rad) 
Groark, A. L., Tindale, C. W. (2008). Good Reasoiong Matters!, Oxford University Press, Oxford.

Gupta, B. (1995). Perceiving in Advanta Vedanta: Epistemiological Analysis and Interpretation, MontialBanarsidass, Delhi.

Hamblin, C. L. (1970). Fallacies, Methuen, London.

Kišiček, G. (2010). „Pogreške u argumentaciji - Dvojbe u tumačenjuiklasifikaciji“, Govor, XXVII (2), pp. 129-143.

Klaić, B. (2012). Novi rječnikstranihriječi, Školskaknjiga, Zagreb.

Le Bon, G. (1920). Psihologijagomile, Tisakkraljevskezemaljsketiskare, Zagreb.

Mayer, M., Carilho, M. M., Timmermans, B. (2008). PovijestretorikeodGrka do naših dana, Disput, Zagreb.

Mirković, J. (2014). Argumentacija u govorimadruštvenihpokreta, FilozofskifakultetSveučilišta u Zagrebu, Zagreb. (napomena: diplomski rad)

Nušić, B. (1934). Retorika: Nauka o besedništvu, GecaKon, Beograd.

Perelman, C. (1982). The realm of rhetoric, Universitiy of Notre Dame Press, London.

Perelman, C., Obrechts-Tyteca, L. (1969). The new rhetoric: a treatise on argumentation, University of Notre Dame Press, Notre Dame.

Petrović, S. (2007). Retorika: Istorija, teorija, praksa, Narodnaknjiga - Alfa.

Radonjić, R. (1999). Govorništvo, CID, Podgorica.

Radonjić, R. (2006). Pravnaretorika, Pobjeda, Podgorica.

Schmidt, M. (1986).,On classifications of fallacies“, Informal Logic, VIII (2), pp. 57-66.

Simović, M. N., Simović, V. M. (2016). Krivičnoprocesnopravo, Uvodiopštidio, PravnifakultetUniverziteta u Bihaću, Bihać.

Škarić, I. (2004). Skriptazamentoregovorničkeškole.

Škarić, I. (2011). Argumentacija, Globus, Zagreb.

Sloane, T. O. (2001).Encyclopedia of Rhetoric, Oxford University Press, New York.

Tadić, Lj. (1995). Retorika, Uvod u veštinubesednišstva, Filip VišnjićInstitutzafilozofijuidruštvenuteoriju, Beograd.

Thagard, P. (1983). „Fallacies of practical reasoning“, Informal Logic, V (1), pp. 26-27.

Tindale, C. (2007). Fallacies and Argument Appraisal (Critical Reasoning and Argumentation), Cambridge University Press, Cambridge - New York.

Tindale, C. W. (1999). Acts of Arguing: a rhetorical model of arguing, State University of New York Press, New York.

Van Eemeren, F. H, Grootendorst, R. (2004).A Systematic Theory of Argumentation, The PragmaDialectical Approach, Cambridge University Press, Cambridge.

Van Eemeren, F. H., Garssen, B., Krabbe, E. C. W., SnoeckHenkemans, A. F., Verheij, B., Wagemans, J. H. (2014). Handbook of Argumentation Theory, Springer, Dordrecht.

Walton, D. (2005). Fundamentals of Critical Argumentation, Cambridge University Press, Cambridge. 
Weston, A. (1992). A Rulebook for Arguments, Hackett Publishing Company, Indianapolis Cambridge.

Zarefsky, D. (2014). Rhetorical Perspectives on Argumentation, Selected Essays by David Zarefsky, Springer, Cham. 